\title{
News from the Chicago Area
}

\section{J. Carroll Moody}

Northern Illinois University

A wide range of labor history and related projects has involved a variety of scholars, union members, and the general public during the past several months. The Illinois Labor History Society has taken the lead in most of the significant activities. The Society sponsored a highly successful conference in November, celebrating "100 Years of Organized Labor in Illinois" (reported in the previous issue of ILWCH). The ILHS is also involved in two projects funded by the Illinois Humanities Council: one, a history of carpenters' unionism in Illinois, now being completed by Richard Schneirov and Thomas Suhrbur in conjunction with the 100th anniversary of the founding of the United Brotherhood of Carpenters; and the other, the production of a documentary film, “Pullman Town," directed by filmmaker Martin Buechley. The Society also raised the funds necessary to restore the Haymarket Martyrs Monument in Forest Home Cemetery, which was defaced by unknown vandals. A rededication ceremony in May attracted some one hundred persons, including $\mathrm{O}$. W. and James Neebe, grandsons of Oscar Neebe, one of the martyrs. A French television crew filmed the ceremonies. In March three officers of the Society presented a "Back-to-Basics" labor history program for the Peoria Building Trades Council. ILHS president Leslie Orear talked about "A Century of Struggle"; William Adelman of the University of Illinois presented his popular illustrated talk on "Labor History Rediscovered," and William Bork of Roosevelt University discussed "The Building Trades in the Open Shop Drive of the 1920s." Stephen Freedman of the University of Chicago traced the history of the Peoria labor movement. In May, the Society inducted two new members into its "Union Hall of Honor" at a dinner attended by some 150 union people and friends. Ralph Helstein, president-emeritus of the United Packinghouse Workers was present to be honored, and Milton P. Webster, chairman of the executive board of the Brotherhood of Sleeping Car Porters was honored posthumously.

The ILHS plans two major events during the coming months. On November 7 in cooperation with Roosevelt University, a public program celebrating the 50th anniversary of the election of Franklin D. Roosevelt as president will be held, featuring a panel of historians, a specially-created slide show, and a discussion of veteran workers of the New Deal era. The Society is also cooperating with the Chicago Federation of Labor in sponsoring a Labor Day Parade in commemora- 
ting the 100th anniversary of the first such parade in New York City. This will be the first labor day parade held in Chicago in many years.

Since most of its programs are designed to serve a broad group, the ILHS promoted the creation of a "working group" of researchers, called the Chicago Area Labor History Group. For almost a year graduate students and faculty from the area's universities have met periodically at the Newberry Library in Chicago to discuss papers prepared by participants. Papers presented during 1981-1982 were: “'For Whom Are All the Good Things in Life?': German-American Housewives Discuss Their Budgets," by Dorothee Schneider; "The Mutability of the Sexual Division of Labor: The Transformation of Clerical Work," by Susan E. Hirsch; "Mechanical Engineers and Machinists: Machine Tool Technology and the Transfer of Skills, 1900-1930," by Stephen Meyer; "The Origin of the Modern State in Chicago, 1871-1879," by Richard Schneirov; "Counting Anarchists: Numbers and Patterns in Anarchist Organizations in Chicago, 1880-1886," by Bruce C. Nelson; and "The Evolution of Class Relations in Rockford, Peoria, and Joliet, 1870-1920," by Stephen Freedman.

Several other labor history projects have been held or are underway in the northern area of Illinois. Since October 1980, Northern Illinois University, the Aurora Trades and Labor Assembly and union locals, with funding in part by the Illinois Humanities Council, have been conducting the Aurora Workers' Research and Education Project. Programs for union members have included labor films, discussions on contemporary labor and economic problems, and workshops on preserving union records, writing labor history, and doing oral history. In Joliet, a local group sponsored by the Will-Grundy Counties Central Trades and Labor Council, Illinois State University, and the Joliet Teacher Corps Project has produced a film, "Roll the Union On-Will County Labor History: 1870-1920." The film was first shown at the Images of Labor show at Joliet Junior College, along with sculptures and paintings treating coal miners, quarry workers, wallpaper and steel workers. During the coming year, the Union Printers Historical Society will sponsor a program celebrating the 150th anniversary of the birth of printing in Chicago. 